\title{
The evolution of high-alumina basalts of the Klyuchevskoy volcano, Kamchatka, Russia, based on microprobe analyses of mineral inclusions
}

\author{
Alexei Y. Ozerov \\ Institute of Volcanology, Petropavlovsk-Kamchatsky, 683006, Russian Federation
}

Received 28 November 1994; accepted 24 June 1999

\begin{abstract}
The origin of calc-alkaline high-alumina basalts (HAB) of the Klyuchevskoy volcano, Kamchatka, was examined using electron microprobe analyses of phenocrysts and mineral phases included in the phenocrysts. Continuous trends on major-element variation diagrams suggest the $\mathrm{HAB}$ were derived from high-magnesia basalt (HMB) by fractional crystallization. Phenocrysts in the HAB are strongly zoned: olivine (Mg\# 91-64), clinopyroxene $\left(\mathrm{Wo}_{45-38} \mathrm{En}_{40-51} \mathrm{Fs}_{5-20}\right)$ and chrome-spinel/magnetite inclusions in them $\left(\mathrm{Cr}_{2} \mathrm{O}_{3} 45-0\right.$ wt. $\%, \mathrm{TiO}_{2}$ 0.5-11\%). Microprobe analyses of minerals included in the phenocrysts provide additional constraints on the mineral crystallization trends in the $\mathrm{HAB} . \mathrm{Fe} / \mathrm{Mg}$ partitioning data, when applied to the phenocrysts cores, show they crystallized from a HMB. The similarity of phenocryst core compositions in HAB with those in HMB strongly suggests a genetic relationship between the two magma types. (C) 2000 Elsevier Science B.V. All rights reserved.
\end{abstract}

Keywords: high-alumina basalts; crystallization; phenocryst

\section{Introduction}

The origin of high-alumina basalt (HAB) has been a long-standing controversy in petrology ever since it was recognised that such rocks are important and common product of island-arc magmatism (Kuno, 1960). The principal debate has centered on whether $\mathrm{HAB}$ are primary magmas formed by partial melting of subducted oceanic crust and associated sediments (e.g., Marsh and Carmichael, 1974; Baker and Eggler, 1983; Brophy and Marsh, 1986; Johnston, 1986), or are the product of fractionation of a high-magnesia basalt (HMB) parent (Perfit et al., 1980; Kay and Kay, 1985; Kadik et al., 1989; Draper and Johnston,
1992). Other models for the origin of HAB include accumulation of plagioclase crystals in a magnesian magma (e.g., Brophy, 1989; Fournelle and Marsh, 1991) and reequilibration of a melt with the surrounding conduit (Kelemen, 1990).

The Klyuchevskoy volcano is an ideal place to examine the relationship between HAB and HMB, as both have been erupted and have a close spatial relationship to each other (Khrenov et al., 1989; Ozerov and Khubunaya, 1992; Kersting and Arculus, 1994). HAB is the dominant basalt type on the volcanically active Kamchatka arc (Volynets et al., 1976). The primary goal of this paper is to examine the genetic relationship between the HAB and $\mathrm{HMB}$ 
magma types using microprobe analyses of phenocryst phases and mineral grains included in phenocrysts. The microprobe data help elucidate the crystallization sequence of the HAB and, when the compositions of mineral inclusions in $\mathrm{HAB}$ are compared to phenocrysts compositions in HMB, suggest a genetic relationship between the two magma types. This paper compliments recent geochemical and petrologic studies (Kersting and Arculus, 1994, 1995; Ariskin et al., 1995; Ozerov et al., 1996) on samples from Klyuchevskoy which suggest that polybaric fractionation of a hydrous $\left(2 \% \mathrm{H}_{2} \mathrm{O}\right) \mathrm{HMB}$ parent can give $\mathrm{HAB}$.

The Klyuchevskoy volcano, $\left(56^{\circ} 07^{\prime} \mathrm{N}, 160^{\circ} 08^{\prime} \mathrm{E}\right)$ (Fig. 1) located within the Central Kamchatka De- pression, is $4800 \mathrm{~m}$ high and rises $2900 \mathrm{~m}$ above local ground level. It is a classic stratovolcano composed of lava flows, pyroclastic deposits, and ice interlayers. Presently, it is one of the most active arc volcanoes in the world. It is mostly Holocene in age and has formed mainly in the last 7000 years. Klyuchevskoy has a main, central vent but has also produced numerous flank eruptions (Fig. 2). The cone contains an oval-shaped summit crater $750 \mathrm{~m}$ in diameter.

Eruptions from the summit crater differ in duration and intensity. Eruptive activity may last from several weeks to three or more years. Repose periods between eruptions have lasted from one month to ten years. Several types of summit activities have been

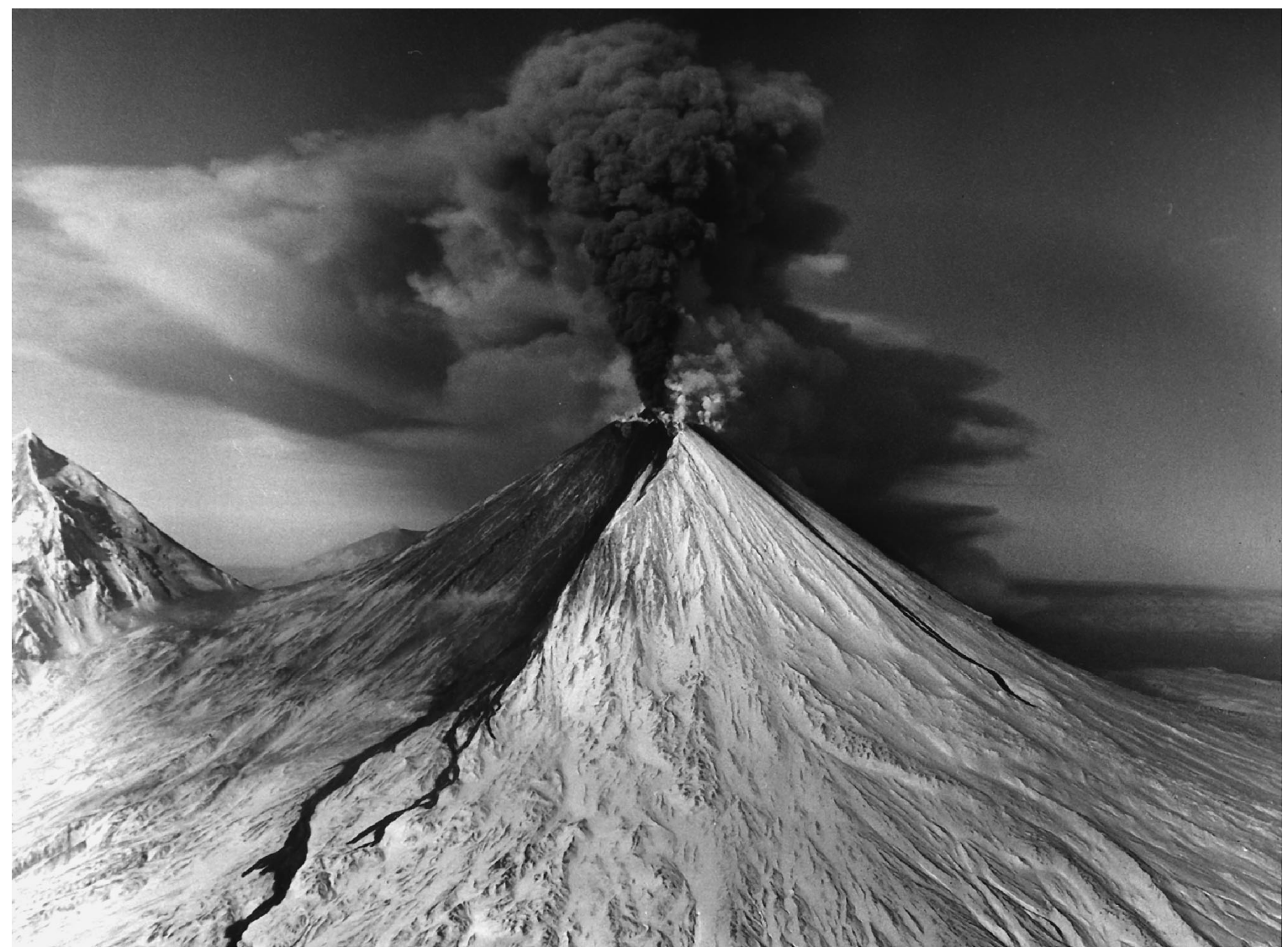

Fig. 1. Klyuchevskoy volcano, $4800 \mathrm{~m}$ high, during the summit eruption of 1987. Several lava flows are descending the mountain. The stratovolcano has a classic symmetrical shape. Kamen which is $4575 \mathrm{~m} \mathrm{high}$, an extinct deeply eroded mainly basaltic volcano, is on the left. The view is looking to the west. 


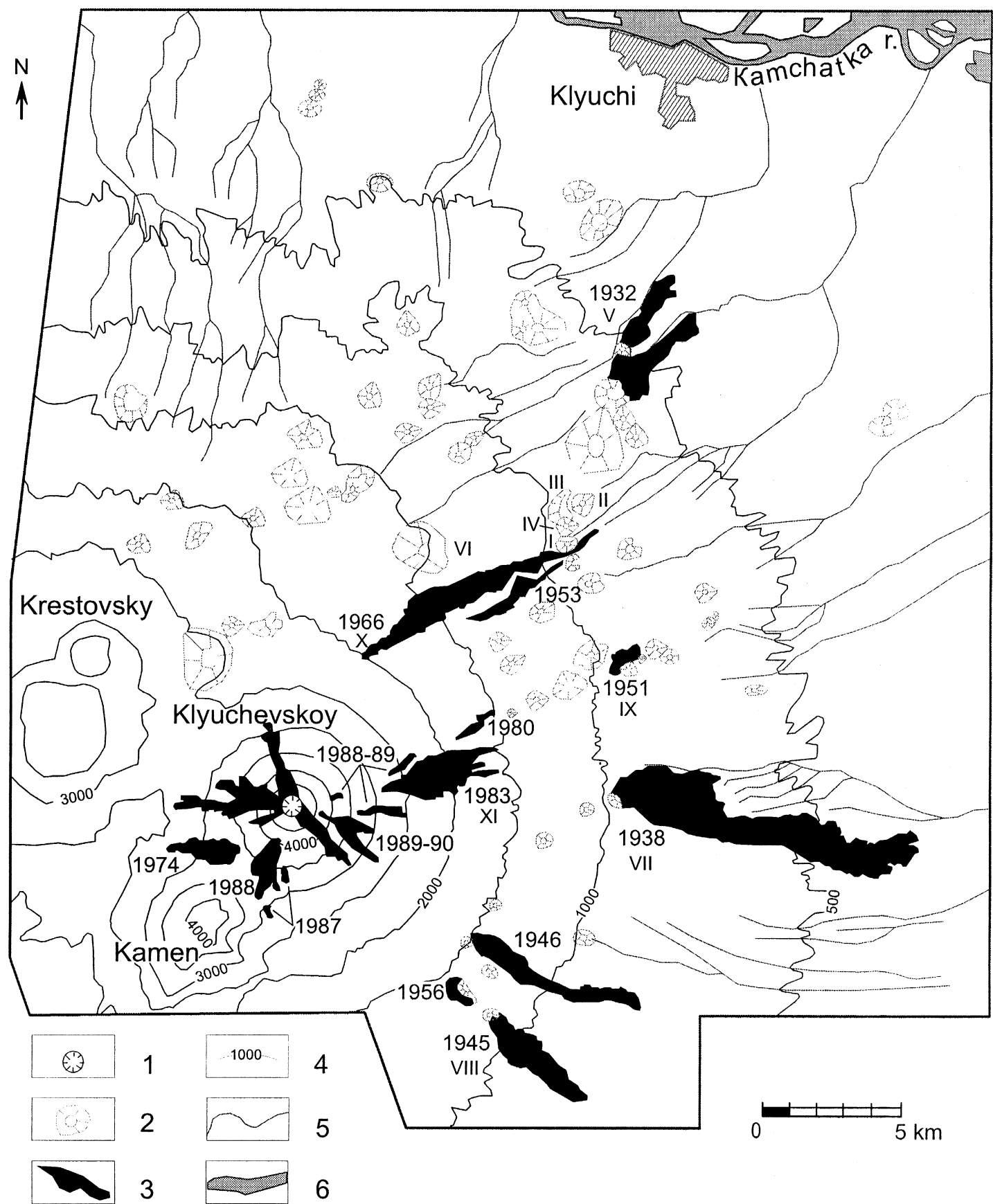

Fig. 2. Sketch map showing the sites of flank eruptions and historic lava flows from Klyuchevskoy volcano. 1 - Summit of crater of Klyuchevskoy; 2 - cinder cones; 3 - lava flows from historic eruptions; 4 - contours; 5 - dry river - beds; 6 - Kamchatka river. Samples examined in this study were collected from the following vents: I — Bulochka, II — Nezametny, III — Luchitsky, IV — Novograblenov, V - Tuila, VI — Slyunin, VII — Bilyukai, VIII - Zavaritsky, IX - Bylinkina, X - Piip, XI - Predskazany. 
observed during the course of a single eruption. Vulcanian type explosions of low to moderate intensity produce ash plumes without lava present in the crater. During other times, lava fountaining and lava flows, or Strombolian-like eruptions, are observed. Lava flows produced by summit eruptions have not been observed to descend lower than 1000-2000 m below the summit. Very strong, Plinian paroxysmal eruptions are rare at Klyuchevskoy, but a spectacular example occurred on the 1st of October 1994 (Ozerov et al., 1997b).

Over 80 flank eruptions, mainly confined to the eastern slopes of the volcano (Fig. 2) have formed lava flows and cinder cones. The first historic flank eruptions took place in 1932, and since then, 15 other flank eruptions have occurred. Flank eruptions have occurred from vents ranging from 450 to 4400 $\mathrm{m}$ in elevation. The duration of flank eruptions ob- served since 1932, has been between 5 days and 13 months, with the volume of the erupted material ranging from 0.0006 to $0.24 \mathrm{~km}^{3}$. Lava flows are generally between 0.8 and $10 \mathrm{~km}$ in length and from 2 to $50 \mathrm{~m}$ in width. In some cases, $200 \mathrm{~m}$ high cinder cones have formed at the vent, whereas in others, no products of explosive eruption have been observed (Ozerov et al., 1997a).

\section{Samples and analytical methods}

Flank cinder cones and lava flows on the Klyuchevskoy volcano, were sampled in detail. Wherever possible, samples lava erupted at various times during an eruptive episode were collected. HAB's $(\mathrm{MgO}=5-6$ wt.\%) were sampled from the 1945 Zavaritsky, 1951 Bylinkina, 1966 Piip, and
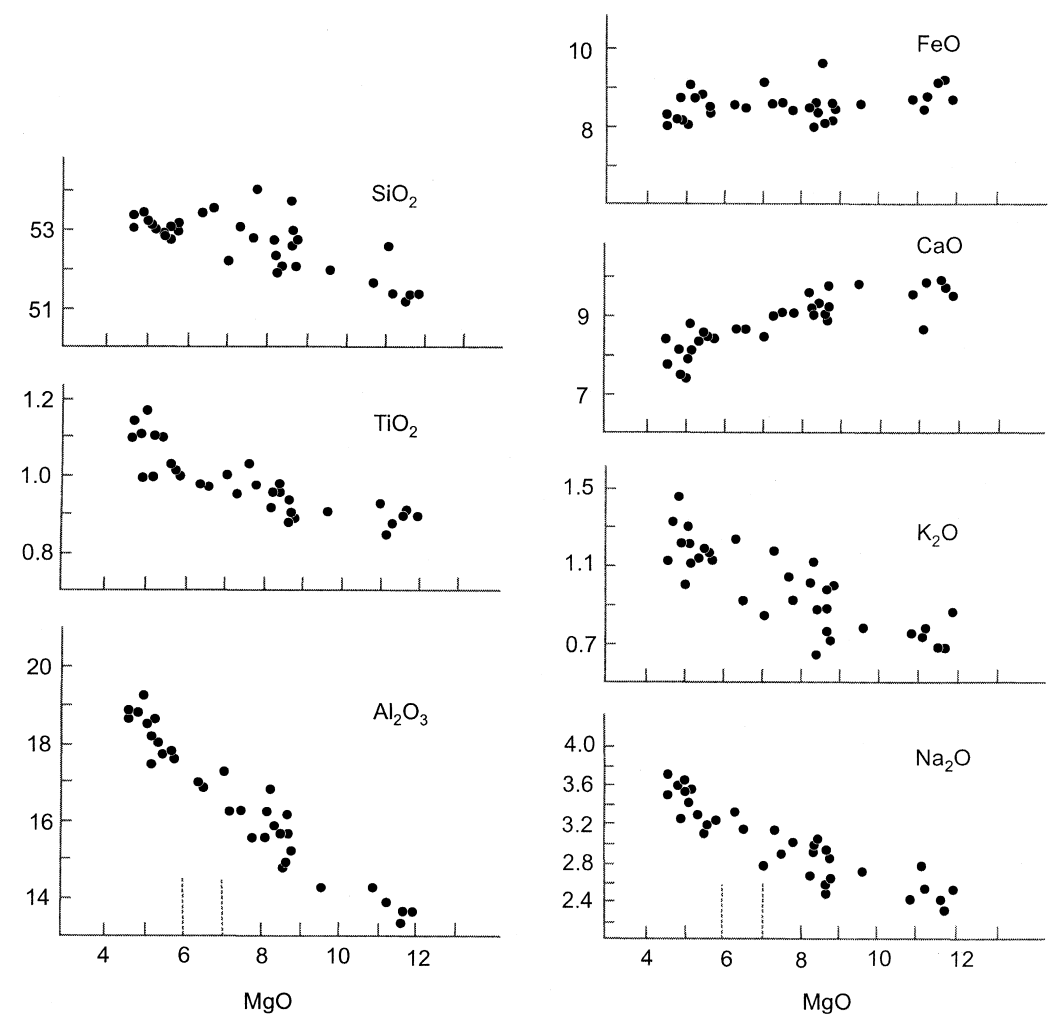

Fig. 3. Variation diagrams showing the compositions of lavas from over 30 flank eruptions from Klyuchevskoy volcano. Samples with $<6$ wt.\% $\mathrm{MgO}$ are high-alumina basalts (HAB) whereas those with $>7 \mathrm{wt} \% \mathrm{MgO}$ are referred to as high-magnesia basalts (HMB). Two intermediate samples with 6-7 wt. $\% \mathrm{MgO}$ are termed magnesia basalts. The coherence of the chemical trends is consistent with formation of the HAB by fractionation of olivine and pyroxene from a parental HMB. 
1983 Predskazanny flank eruptions. HMB's with varying $\mathrm{MgO}$ contents were collected from the pre1932 flank eruptions at the Bulochka $(\mathrm{MgO}=11.92$ wt.\%), Nezametny (11.67\%), Luchitsky (11.17\%), Novograblenov (10.94\%), and Slyunin (8.65\%), and from the 1932 Tuila $(8.71 \%)$ and 1938 Bilyukai (7.04\%) flank eruptions (Fig. 2).

Whole rock wet chemical analyses were made at the Institute of Volcanology, PetropavlovskKamchatsky, using photocolorimetry $\left(\mathrm{SiO}_{2}, \mathrm{TiO}_{2}\right.$, $\mathrm{Al}_{2} \mathrm{O}_{3}, \mathrm{Fe}_{2} \mathrm{O}_{3}$ and $\mathrm{P}_{2} \mathrm{O}_{5}$ ), atomic absorption $(\mathrm{MgO}$, $\mathrm{CaO}$ and $\mathrm{MnO})$, flame photometry $\left(\mathrm{Na}_{2} \mathrm{O}\right.$ and $\left.\mathrm{K}_{2} \mathrm{O}\right)$, volumetric methods $(\mathrm{FeO})$, Penfield techniques $\left(\mathrm{H}_{2} \mathrm{O}^{+}\right)$and loss on heating at $105^{\circ} \mathrm{C}\left(\mathrm{H}_{2} \mathrm{O}^{-}\right)$. From 3 to 20 chemical analyses were made to characterize each separate flank eruption.

Olivine and pyroxene were separated from crushed and sieved samples using bromoform heavy liquid separations. Samples were purified by handpicking under a binocular microscope and then arranged on a glass slide and covered with epoxy resin. The slides were ground and polished to expose the middle of the grains. Each specimen contained as many as 100 grains of mafic minerals. In order to understand the sequence of the HAB crystallization sequence, we also performed microprobe analyses of olivine and pyroxene inclusions $(10-50 \mu \mathrm{m}$ in size) in olivine, pyroxene and plagioclase phenocrysts.
Olivine, pyroxene and plagioclase were analysed at the Institute of Volcanology, Kamchatka, by a Cameca Camebax electron microprobe using a $20-\mathrm{kV}$ accelerating voltage and a $40-n A$ beam current. Labradorite (ISNM 115900) was used as the standard for $\mathrm{Si}, \mathrm{Al}$, and $\mathrm{Na}$; diopside for $\mathrm{Ca}$; olivine $\left(\mathrm{Fo}_{77}\right)$ for $\mathrm{Mg}$ and $\mathrm{Fe}$; sanidine with $12 \% \mathrm{~K}_{2} \mathrm{O}$ for $\mathrm{K}$; and ilmenite, rhodonite and chrome-spinel, for $\mathrm{Ti}, \mathrm{Mn}$ and $\mathrm{Cr}$, respectively. For each eruption we analysed the core and rim of at least 70-100 grains of olivine and pyroxene.

The degree of evolution of olivine and pyroxene were compared using the $\mathrm{Mg}$ number $(\mathrm{Mg} \#=\{(\mathrm{Mg}$ $\times 100) /(\mathrm{Mg}+\mathrm{Fe})\}$ atomic $)$ because this parameter reflects changes in the crystallization conditions.

\section{Results}

\subsection{Petrography}

HAB from the flanks eruptions have seriate porphyritic textures with phenocrysts and glomeroporphyritic aggregates of plagioclase $(5-10 \%)$, olivine $(<1 \%)$, clinopyroxene $(<1 \%)$ and very rare orthopyroxene. The same phases occur in the groundmass along with magnetite and pigeonite. Spinel occurs as inclusions in phenocrysts. Petrographically,

Table 1

Average analyses of basalts from Klyuchevskoy volcano

\begin{tabular}{|c|c|c|c|c|c|c|c|c|c|c|}
\hline \multirow[t]{2}{*}{ Eruptions } & \multicolumn{10}{|c|}{ Concentration of rock-forming oxides, wt.\% } \\
\hline & $\overline{\mathrm{SiO}_{2}}$ & $\mathrm{TiO}_{2}$ & $\mathrm{Al}_{2} \mathrm{O}_{3}$ & $\mathrm{FeO}^{*}$ & $\mathrm{MnO}$ & $\mathrm{MgO}$ & $\mathrm{CaO}$ & $\mathrm{Na}_{2} \mathrm{O}$ & $\mathrm{K}_{2} \mathrm{O}$ & $\overline{\mathrm{P}_{2} \mathrm{O}_{5}}$ \\
\hline Bulochka (6) & 51.43 & 0.90 & 13.60 & 8.70 & 0.16 & 11.92 & 9.44 & 2.49 & 0.85 & 0.14 \\
\hline Nezametny (1) & 51.38 & 0.91 & 13.51 & 9.40 & 0.19 & 11.67 & 9.68 & 2.28 & 0.68 & 0.15 \\
\hline Luchitsky (4) & 51.39 & 0.88 & 13.83 & 8.70 & 0.16 & 11.17 & 9.75 & 2.52 & 0.76 & 0.15 \\
\hline Novograblenov & 51.66 & 0.93 & 14.18 & 8.70 & 0.16 & 10.94 & 9.45 & 2.39 & 0.74 & 0.14 \\
\hline Tuila (3) & 52.70 & 0.74 & 14.88 & 8.30 & 0.18 & 8.71 & 9.70 & 2.55 & 0.97 & 0.19 \\
\hline Slyunin (7) & 53.79 & 0.85 & 14.71 & 8.60 & 0.16 & 8.65 & 8.98 & 2.44 & 0.76 & 0.16 \\
\hline Bilyukai (18) & 53.08 & 0.86 & 16.45 & 8.56 & 0.19 & 7.04 & 8.99 & 2.92 & 1.06 & 0.20 \\
\hline Zavaritsky (11) & 53.13 & 1.03 & 17.72 & 9.32 & 0.17 & 5.58 & 8.46 & 3.10 & 1.18 & 0.18 \\
\hline Bylinkina (5) & 53.05 & 1.11 & 18.48 & 8.31 & 0.15 & 5.12 & 7.93 & 3.49 & 1.30 & 0.24 \\
\hline Piip (9) & 53.15 & 1.05 & 17.61 & 8.51 & 0.16 & 5.76 & 8.43 & 3.25 & 1.13 & 0.22 \\
\hline Predskazany (15) & 53.04 & 1.03 & 18.13 & 8.96 & 0.17 & 5.22 & 8.18 & 3.40 & 1.22 & 0.21 \\
\hline $\begin{array}{l}\text { Summit eruption of } \\
1984-1986 \text { (13) }\end{array}$ & 53.28 & 0.99 & 18.25 & 8.75 & 0.17 & 4.96 & 8.12 & 3.24 & 1.23 & 0.17 \\
\hline
\end{tabular}

No. of analyses is shown in brackets. Analyst A.M. Okrugina, Central Chemical Laboratory of the Institute of Volcanology.

* Total $\mathrm{Fe}$ as $\mathrm{FeO}$. 
we could not determine the crystallization sequence in HAB's because the interrelationships between crystals were seldom observed.

HMB's from flank eruptions are porphyritic with glomeroporphyritic aggregates $(2-4 \mathrm{~mm})$ of olivine $(\sim 10 \%)$, clinopyroxene $(5 \%)$, rare orthopyroxene and occasional chrome-spinel. Olivine, clinopyroxene, orthopyroxene, pigeonite, plagioclase and magnetite occur in the groundmass.

\subsection{Plagioclase}

Plagioclase is ubiquitous in the HAB. Its largest crystals (up to $2 \mathrm{~mm}$ ) occur in the Piip eruption products; in all other eruption products, crystals are usually smaller, seldom reaching $1.5 \mathrm{~mm}$. Plagioclase crystals are usually euhedral and tabular, or oblong-prismatic in form. Oscillatory zoning is observed. Occasionally, small glass and mafic mineral inclusions are found both in the cores and rims of plagioclase.

Plagioclase phenocrysts vary widely, from $\mathrm{An}_{84-85}$ in the cores to $\mathrm{An}_{50-53}$ in the rims. Subphenocrysts have cores of $\mathrm{An}_{80}$ and rims of $\mathrm{An}_{50}$. Reverse zoning occurs occasionally. The composition of microlites is similar to that of the rims of subphenocrysts.

\subsection{Olivine}

In the $\mathrm{HAB}$, olivine is second in abundance after plagioclase. Large aggregates (more than $1.5 \mathrm{~mm}$ ) are extremely rare, but smaller crystals are common. Many olivine crystals are euhedral, but anhedral crystals also occur. Small aggregates of spinel, mafic minerals and melt inclusions are common in phenocrysts and can be found in any part of the olivine crystal. Microlites of olivine are usually subhedral to euhedral; occasionally one can observe skeleton forms, such as hollow rectangles, rhombs, and arrows formed by rapid quench crystallization. Microlites with thin reaction rims also occur. The microlites usually do not contain mineral inclusions, except for occasional magnetites.

Olivine phenocrysts range from cores of $\mathrm{Mg \#}$ 90-78 to rims of $\mathrm{Mg \#} \mathrm{68.} \mathrm{In} \mathrm{subphenocrysts,} \mathrm{the}$ cores are $\mathrm{Mg} \#$ 80-70 and the rims $\mathrm{Mg} \#$ 75-65. Microlites show Mg\# 75-64 which is similar to that of the subphenocryst rims.

\subsection{Clinopyroxene}

Clinopyroxene crystals are commonly less than $1.0-1.5 \mathrm{~mm}$ in diameter; but rare single large aggregates reach $3.0-3.5 \mathrm{~mm}$. Large phenocrysts are anhedral, whereas smaller phenocrysts are euhedral. Inclusions of opaque phases, silicates, and glass are also common.

The cores of clinopyroxene are mainly diopside to $\mathrm{Mg}$-rich augite. Subphenocrysts of clinopyroxenes
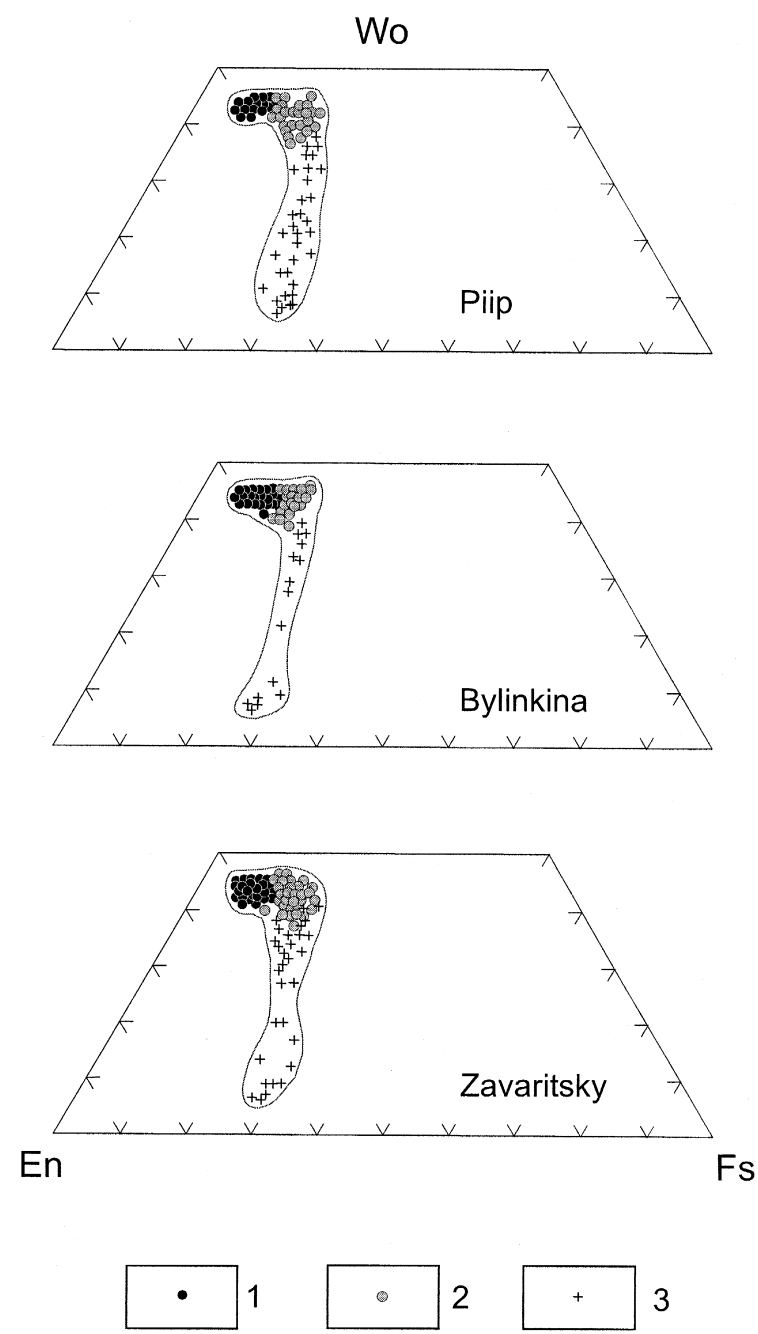

Fig. 4. Microprobe analyses of pyroxene in HAB from the Piip, Bylinkina and Zavaritsky eruptions. En - enstatite, Wo wollastonite, Fs - ferrosilite. 1 - Cores of phenocrysts, 2 rims of phenocrysts, $3-$ microlites. 


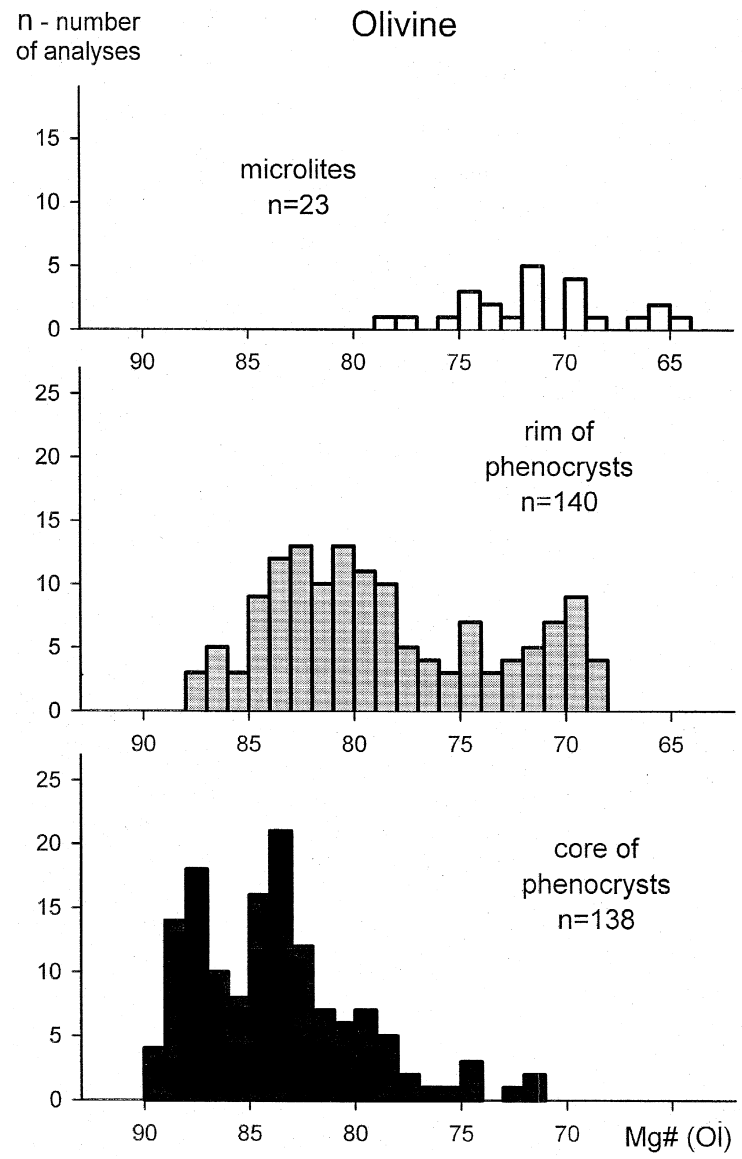

$n-$ number $\quad$ Clinopyroxene
of analyses
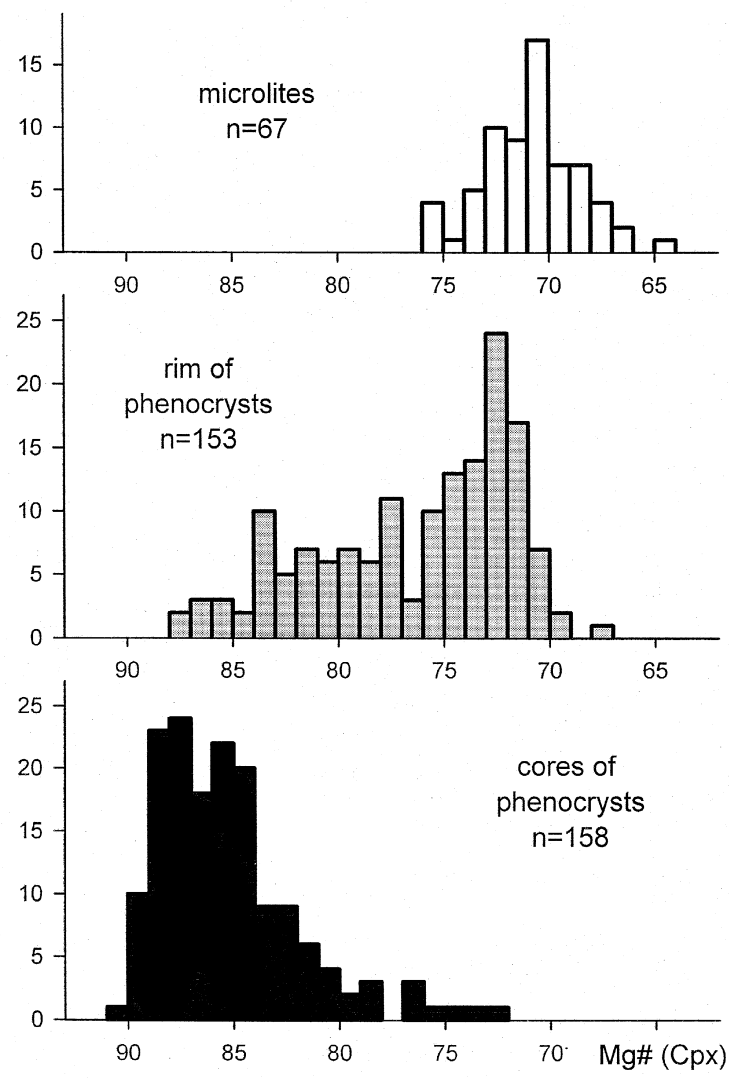

Fig. 5. Variation of magnesium number $(\mathrm{Mg \#})$ in phenocryst cores and rims and groundmass microlites of olivines and clinopyroxenes in $\mathrm{HAB}$ from the Zavaritsky eruption, $n$ - number of analyses.

are richer in iron with ferruginous augite rims. Microlites have the same composition as the rims of the subphenocrysts, but some of them are pigeonite in composition.

Table 2

Representative analyses of olivine composition from the Zavaritsky Vent (mass\%)

\begin{tabular}{lrrrrrr}
\hline & \multicolumn{1}{l}{$\mathrm{C}$} & \multicolumn{1}{l}{$\mathrm{C}$} & \multicolumn{1}{l}{$\mathrm{R}$} & \multicolumn{1}{l}{$\mathrm{R}$} & \multicolumn{1}{l}{$\mathrm{M}$} \\
\hline $\mathrm{SiO}_{2}$ & 40.36 & 39.24 & 38.52 & 37.96 & 37.44 & 36.41 \\
$\mathrm{FeO}$ & 10.28 & 14.00 & 18.88 & 22.85 & 25.94 & 30.00 \\
$\mathrm{MnO}$ & 0.16 & 0.20 & 0.26 & 0.40 & 0.51 & 0.60 \\
$\mathrm{MgO}$ & 48.59 & 45.84 & 42.40 & 38.43 & 35.27 & 32.09 \\
$\mathrm{Total}$ & 99.39 & 99.29 & 100.06 & 99.79 & 99.38 & 99.53 \\
$\mathrm{Mg \#}$ & 89.24 & 85.19 & 79.79 & 74.98 & 70.78 & 65.60 \\
\hline
\end{tabular}

$\mathrm{C}$ - core, $\mathrm{R}$ - rim, $\mathrm{M}$ - microlite.
Table 3

Representative analyses of clinopyroxene composition from the Zavaritsky Vent (mass\%)

\begin{tabular}{lrrrrrr}
\hline & \multicolumn{1}{l}{$\mathrm{C}$} & \multicolumn{1}{l}{$\mathrm{C}$} & \multicolumn{1}{l}{$\mathrm{R}$} & \multicolumn{1}{l}{$\mathrm{M}$} & \multicolumn{1}{l}{$\mathrm{M}$} \\
\hline $\mathrm{SiO}_{2}$ & 55.94 & 53.39 & 52.06 & 51.57 & 48.35 & 50.30 \\
$\mathrm{TiO}_{2}$ & 0.09 & 0.24 & 0.39 & 0.65 & 1.24 & 1.26 \\
$\mathrm{Al}_{2} \mathrm{O}_{3}$ & 1.39 & 2.76 & 3.99 & 2.96 & 4.84 & 4.98 \\
$\mathrm{FeO}$ & 3.44 & 5.23 & 6.28 & 8.68 & 10.58 & 12.44 \\
$\mathrm{MnO}$ & 0.00 & 0.16 & 0.16 & 0.18 & 0.24 & 0.34 \\
$\mathrm{MgO}$ & 17.14 & 16.48 & 15.12 & 14.65 & 13.39 & 12.76 \\
$\mathrm{CaO}$ & 22.06 & 20.97 & 20.94 & 20.06 & 19.35 & 15.22 \\
$\mathrm{Na}_{2} \mathrm{O}$ & 0.15 & 0.19 & 0.30 & 0.28 & 0.20 & 0.41 \\
$\mathrm{Cr}_{2} \mathrm{O}_{3}$ & 0.58 & 0.28 & 0.28 & 0.03 & 0.00 & 0.00 \\
$\mathrm{Total}$ & 100.79 & 99.70 & 99.52 & 99.33 & 98.19 & 98.22 \\
$\mathrm{Mg} \#$ & 89.89 & 84.46 & 80.70 & 75.06 & 69.28 & 64.64 \\
$\mathrm{Wo}$ & 45.41 & 43.60 & 44.54 & 42.48 & 41.84 & 35.66 \\
$\mathrm{En}$ & 49.07 & 47.64 & 44.76 & 43.17 & 40.30 & 41.59 \\
$\mathrm{Fs}$ & 5.52 & 8.76 & 10.71 & 14.35 & 17.86 & 22.75 \\
\hline
\end{tabular}

$\mathrm{C}$ - core, $\mathrm{R}$ - rim, $\mathrm{M}-$ microlite. 


\subsection{Orthopyroxene}

Orthopyroxene occurs as single crystals $0.5-0.1$ $\mathrm{mm}$ in size and in glomeroporphyritic aggregates with clinopyroxene. This mineral is rarely observed in HAB. In samples from the Zavaritsky eruption, only three out of 158 pyroxene grains were orthopyroxenes. In samples from the Piip eruption, two orthopyroxenes were found out of 144 pyroxenes, and in the Bylinkina eruption samples none were observed; probably because of smaller number of pyroxene measurements (88). Compositionally they are $\mathrm{Wo}_{3} \mathrm{Fs}_{72} \mathrm{En}_{25}$.

\subsection{Whole rock geochemistry}

The chemical composition of basalts from over 30 flank eruptions from Klyuchevskoy (Ozerov and Khubunaya, 1992) are plotted in Fig. 3. Each point represents the average composition ( 3 to 20 individual analyses) of basalt from one eruption. Analyses of basalts for which microprobe data are presented here are given in Table 1 and are representative of the numerous flank eruptions. For the purpose of this paper, basalts with $>7 \% \mathrm{MgO}$ are called $\mathrm{HMB}$ and those with $<6 \% \mathrm{MgO}$ are $\mathrm{HAB}$. Two samples with $\mathrm{MgO}$ between $6 \%$ and $7 \%$ are referred to as magne-
ALUMINA BASALTS
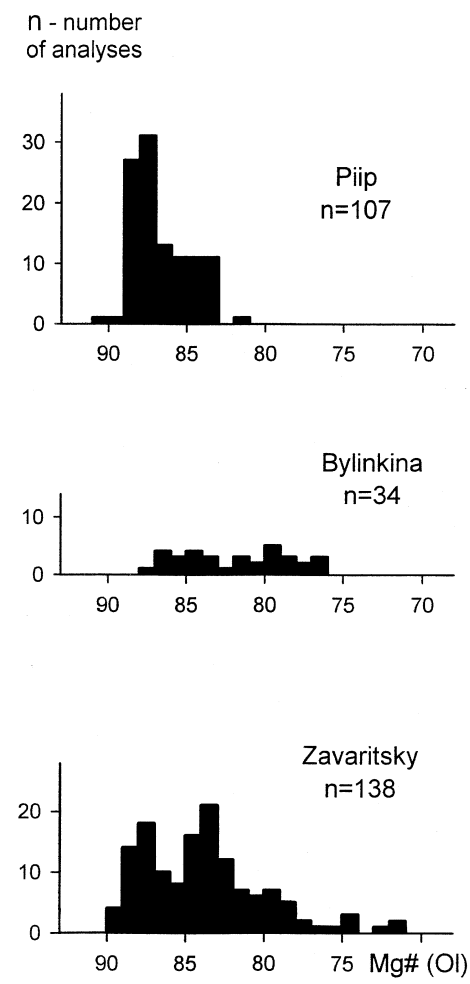

MAGNESIAN BASALTS

$\mathrm{n}$ - number
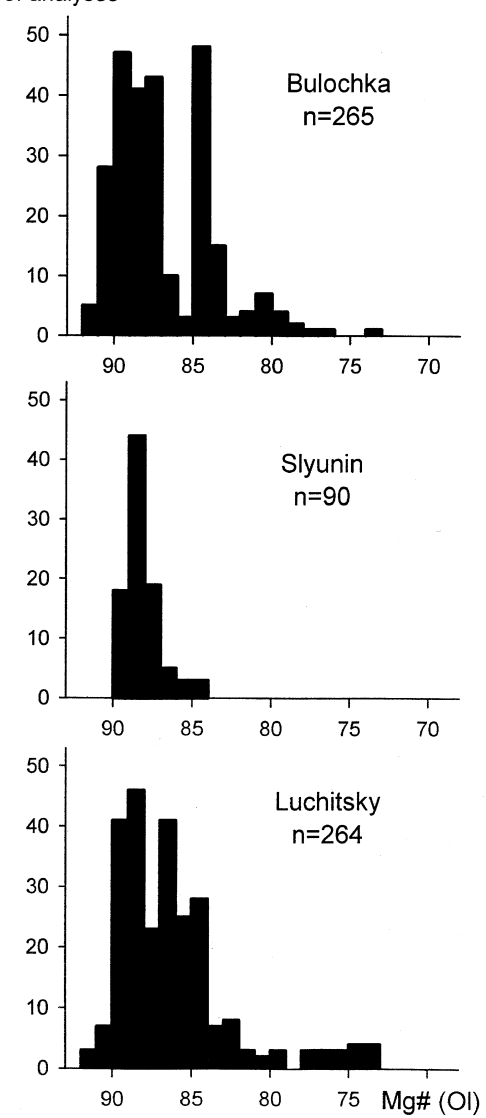

$\mathrm{n}$ - number of analyses
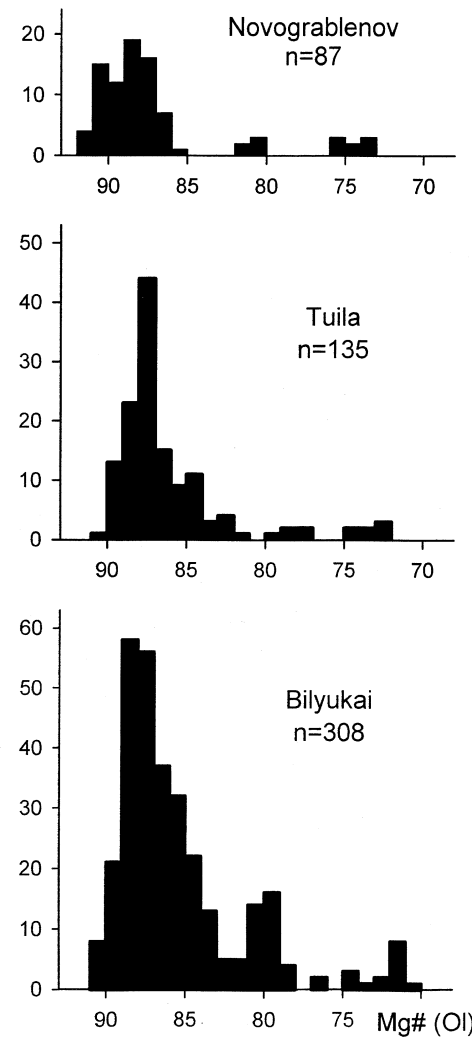

Fig. 6. Comparison of $\mathrm{Mg} \#$ in cores of olivine crystals from three HAB eruptions (left column) and six HMB eruptions (middle and right columns). 
sia basalt. There is an excellent negative correlation between $\mathrm{Al}_{2} \mathrm{O}_{3}$ and $\mathrm{MgO}$ (Fig. 3) and so the $\mathrm{HAB}$ typically has $>17.5 \% \mathrm{Al}_{2} \mathrm{O}_{3}$.

Well-defined negative correlations are observed between $\mathrm{MgO}$ and $\mathrm{SiO}_{2}, \mathrm{TiO}_{2}, \mathrm{Al}_{2} \mathrm{O}_{3}, \mathrm{Na}_{2} \mathrm{O}$, and $\mathrm{K}_{2} \mathrm{O}$ (Fig. 3). A positive correlation is only noted between $\mathrm{MgO}$ and $\mathrm{CaO}$. $\mathrm{FeO}^{*}$ (total $\mathrm{Fe}$ expressed as $\mathrm{FeO}$ ) is independent of $\mathrm{MgO}$ concentrations.

\subsection{Olivines and pyroxenes compositions}

A large number of microprobe analyses were performed on olivine and clinopyroxene phenocrysts and microlites from the Zavaritsky HAB (Figs. 4 and 5; Tables 2 and 3). The Mg\# of olivine and clinopyroxene varies widely even within one sample. In olivine, $\mathrm{Mg} \#$ ranges from 90 to 64 , whereas in clinopyroxene, the range is $91-64$. There is a trend of decreasing $\mathrm{Mg} \#$ from the phenocryst cores which

ALUMINA BASALTS
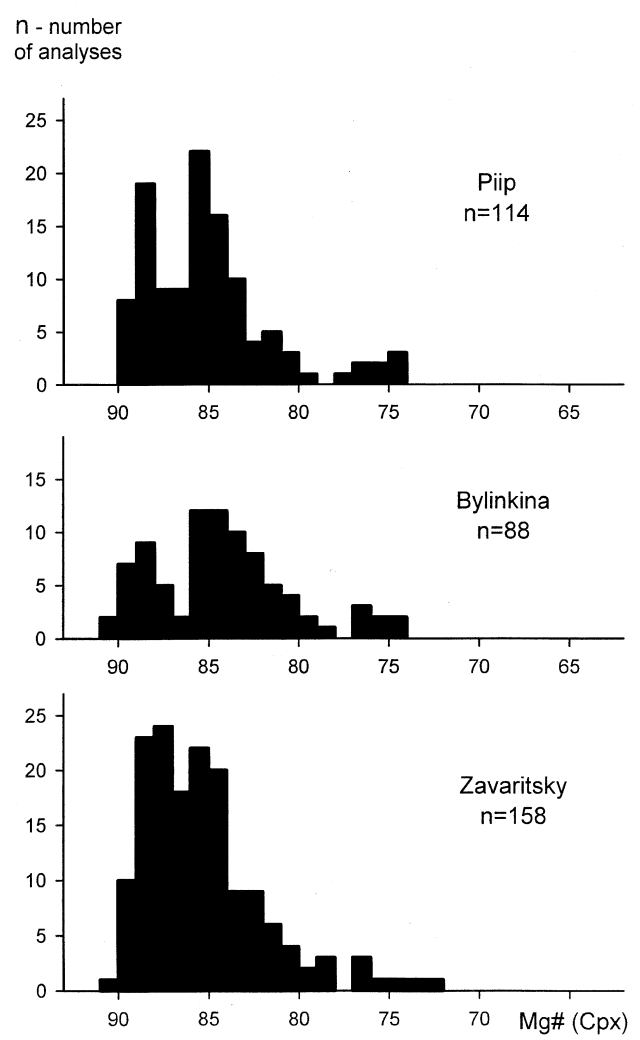

are the most $\mathrm{Mg}$-rich to the rims and finally the microlites are the most $\mathrm{Fe}$-rich. As the clinopyroxene

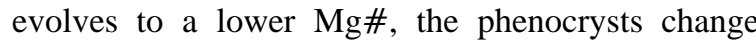
from diopside cores to augite rims whereas the microlites are mainly pigeonite (Fig. 4). Therefore, it is possible to observe the changes in the compositions of olivine and clinopyroxene of HAB basalts during their crystallization.

Similar ranges in $\mathrm{Mg \#}$ are observed in olivine (Fig. 6) and clinopyroxene phenocrysts (Fig. 7) from the Piip and Bylinkina $\mathrm{HAB}$. The range in $\mathrm{Mg \#}$ for the cores of olivine phenocrysts in the Zavaritsky, Bylinkina and Piip eruptions are 90-77, 87-76 and 91-83, respectively (Fig. 6). Although the range for the Bylinkina eruption appear somewhat different, this may be due to insufficient data. The maximum frequency in $\mathrm{Mg \#}$ of olivine cores for the Zavaritsky and Piip eruptions are both between 87 and 84. The ranges of $\mathrm{Mg} \#$ of clinopyroxenes cores (Fig. 7) for

MAGNESIAN BASALTS

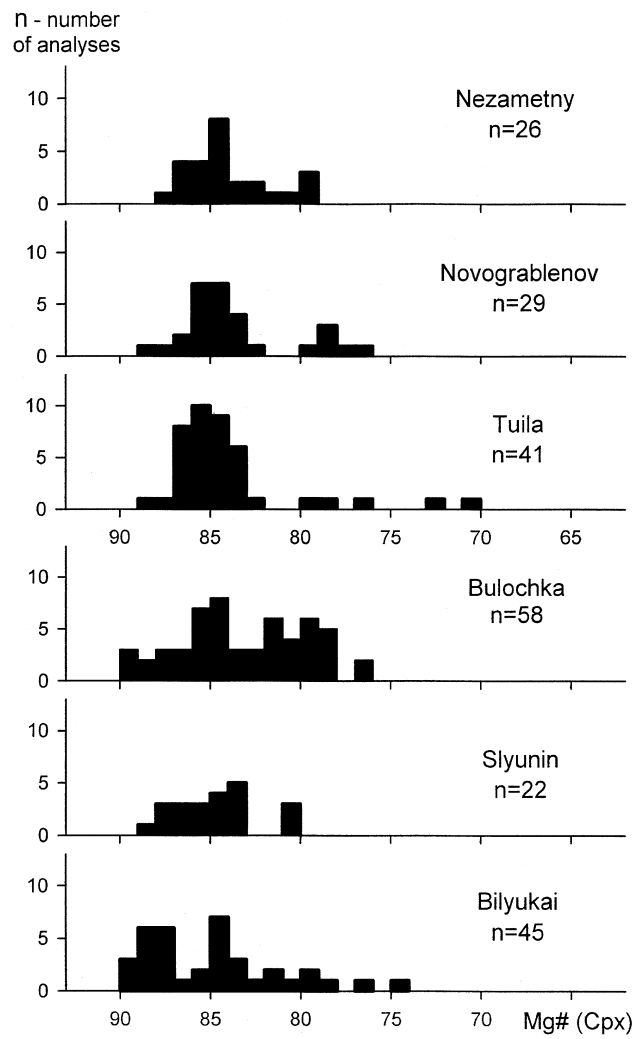

Fig. 7. Comparison of $\mathrm{Mg \#}$ in cores of clinopyroxene crystals from three HAB eruptions (left column) and six HMB eruptions (right column). 

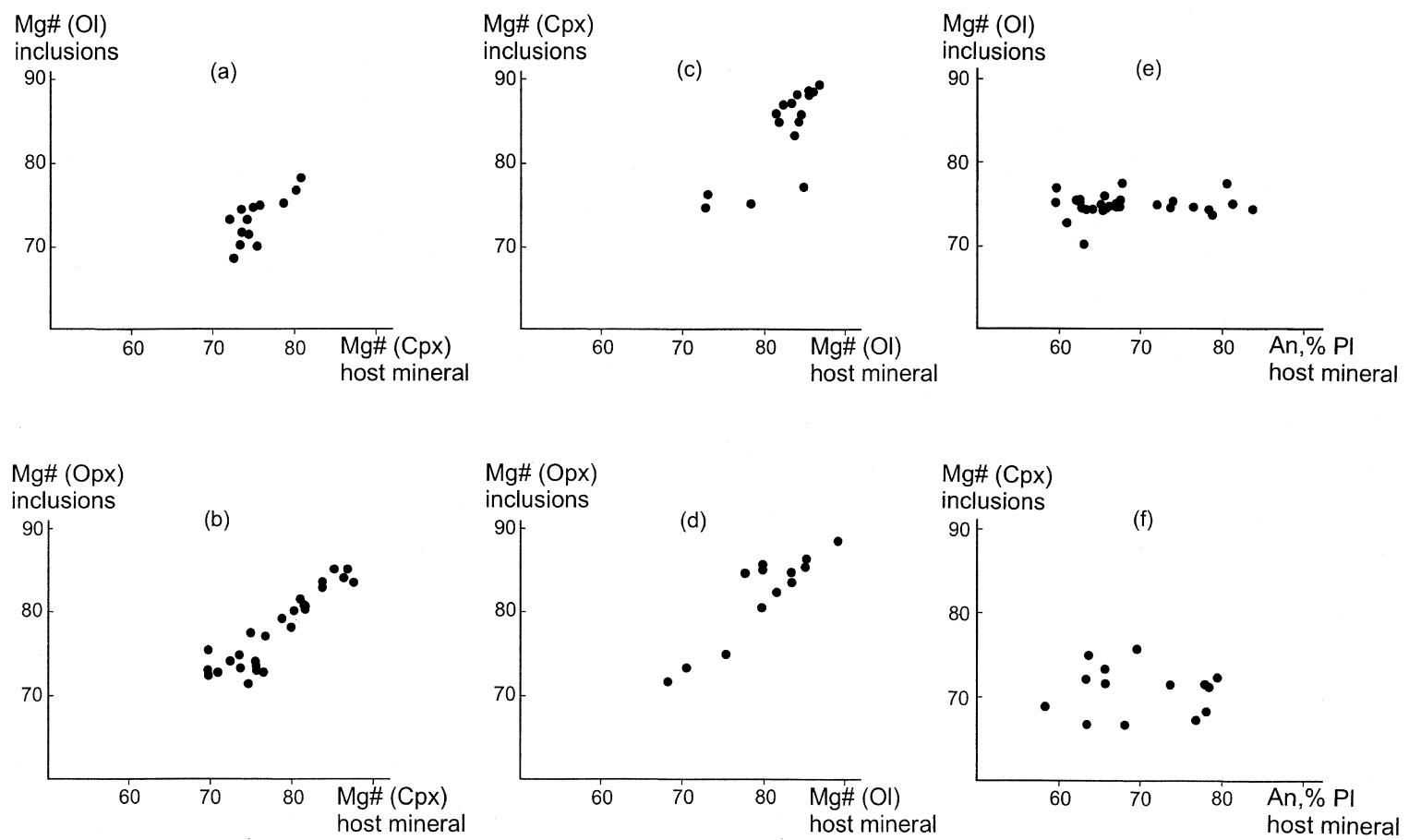

Fig. 8. Variation of $\mathrm{Mg \#}$ in (a) olivine (Ol) and (b) orthopyroxene (Opx) inclusions vs. the $\mathrm{Mg \#}$ of their clinopyroxene (Cpx) host. Variation of $\mathrm{Mg \#}$ in (c) clinopyroxene ( $\mathrm{Cpx}$ ) and (d) orthopyroxene (Opx) inclusions vs. the Mg\# of their olivine (Ol) host. Variation of $\mathrm{Mg \#}$ in (e) olivine (Ol) and (f) clinopyroxene ( $\mathrm{Cpx}$ ) inclusions vs. the anorthite content (An \%) of their plagioclase host.

the Zavaritsky, Bylinkina and Piip eruptions are 91-77, 91-77 and 90-78, respectively, with maximas between 88 and 85 .

The consistency of the $\mathrm{Mg} \#$ in olivine and clinopyroxene from the three HAB eruptions suggest that the phenocrysts formed from a magma of similar composition and they are not xenocrystic material. Also, the consistent trends in $\mathrm{Mg \#}$ from core to rim to the microlites (e.g., the Zavaritsky eruption, Fig. 5) suggests that the melt was chemically evolving as it crystallized. It is believed that the core of compositions of the clinopyroxenes and olivines $(\mathrm{Mg} \#$ $-90-85)$ reflect the composition of the early stages of melt evolution.

To understand the relationship between the HAB and $\mathrm{HMB}$ the $\mathrm{Mg} \#$ of olivine and clinopyroxene in the two rock types were compared. The olivine (Fig. 6) and clinopyroxene (Fig. 7) cores in the HMB have identical $\mathrm{Mg \#}$, even though their whole rock samples have variable $\mathrm{MgO}$ content, and are also identical to those in the HAB. The similarity of the Mg\# in phenocryst cores in the $\mathrm{HAB}$ and $\mathrm{HMB}$ shows that during the early stages of crystallization, the melt compositions in equilibrium with the phe-

Table 4

Representative analyses of orthopyroxene crystals included in olivine $(\mathrm{Ol})$ and clinopyroxene $(\mathrm{Cpx})$ host from the Zavaritsky Vent (mass\%)

\begin{tabular}{|c|c|c|c|c|c|c|}
\hline Host & $\mathrm{Ol}$ & $\mathrm{Ol}$ & $\mathrm{Cpx}$ & $\mathrm{Ol}$ & $\mathrm{Cpx}$ & $\mathrm{Cpx}$ \\
\hline $\mathrm{Mg} \#$ & 88.71 & 86.50 & 80.77 & 79.52 & 72.25 & 74.52 \\
\hline $\mathrm{SiO}_{2}$ & 55.71 & 55.89 & 55.11 & 53.78 & 52.96 & 53.24 \\
\hline $\mathrm{TiO}_{2}$ & 0.05 & 0.08 & 0.10 & 0.11 & 0.15 & 0.29 \\
\hline $\mathrm{Al}_{2} \mathrm{O}_{3}$ & 1.10 & 1.63 & 2.33 & 2.66 & 1.48 & 1.92 \\
\hline $\mathrm{FeO}$ & 7.12 & 9.01 & 11.59 & 12.30 & 15.90 & 17.36 \\
\hline $\mathrm{MnO}$ & 0.17 & 0.11 & 0.14 & 0.28 & 0.26 & 0.39 \\
\hline $\mathrm{MgO}$ & 31.78 & 30.59 & 28.52 & 28.75 & 25.71 & 24.25 \\
\hline $\mathrm{CaO}$ & 1.47 & 1.56 & 1.42 & 1.23 & 1.67 & 1.84 \\
\hline $\mathrm{Na}_{2} \mathrm{O}$ & 0.00 & 0.01 & 0.02 & 0.00 & 0.04 & 0.00 \\
\hline $\mathrm{K}_{2} \mathrm{O}$ & 0.00 & 0.01 & 0.01 & 0.00 & 0.02 & 0.01 \\
\hline $\mathrm{Cr}_{2} \mathrm{O}_{3}$ & 0.51 & 0.02 & 0.01 & 0.00 & 0.00 & 0.14 \\
\hline Total & 97.92 & 98.91 & 99.25 & 99.27 & 98.18 & 99.44 \\
\hline $\mathrm{Mg \#}$ & 88.83 & 85.12 & 81.43 & 80.64 & 74.25 & 71.34 \\
\hline Wo & 2.87 & 3.05 & 2.83 & 2.42 & 3.34 & 3.74 \\
\hline En & 86.26 & 83.20 & 79.12 & 78.68 & 71.77 & 68.67 \\
\hline Fs & 10.85 & 13.75 & 18.05 & 18.89 & 24.89 & 27.59 \\
\hline
\end{tabular}


nocrysts were identical. A clear genetic relationship can be established between the HAB and HMB from the mineral chemistry.

\subsection{Mineral inclusions}

The compositions of olivine and pyroxene grains included in olivine, clinopyroxene and plagioclase phenocrysts from the $\mathrm{HAB}$ also help elucidate the crystallization sequence during magmatic evolution (Fig. 8). The Mg\# of olivine (Fig. 8a) and orthopyroxene (Fig. 8b, Table 4) included in clinopyroxene host crystals show a positive correlation with the $\mathrm{Mg} \#$ of the host. This indicates that the phenocrysts and inclusions were both crystallizing from a magma that was undergoing systematic changes in $\mathrm{Mg}$ con-
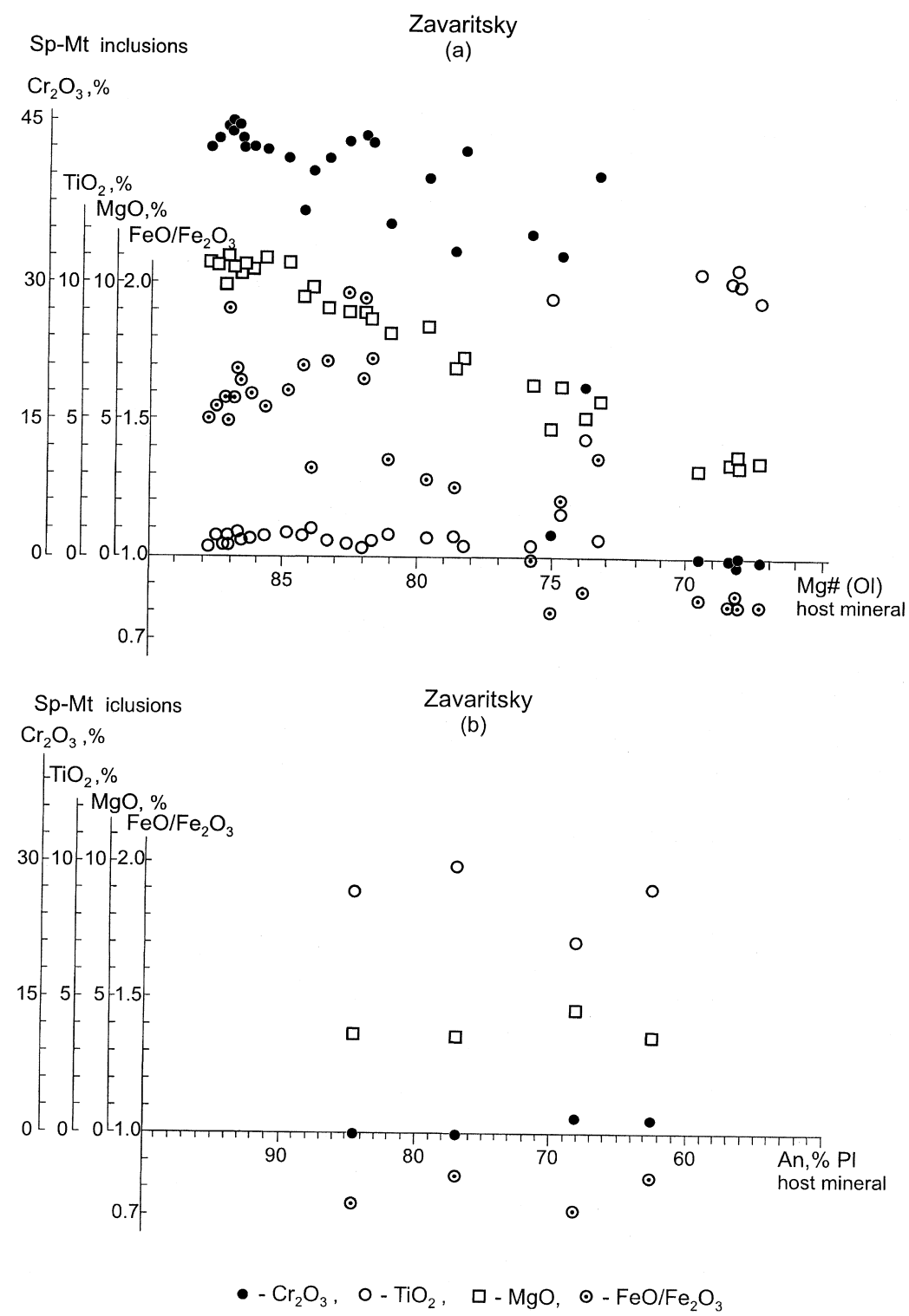

Fig. 9. Variation of $\mathrm{Cr}_{2} \mathrm{O}_{3}$, $\mathrm{TiO}_{2}$ and $\mathrm{MgO}$ concentrations (wt.\%) and $\mathrm{FeO} / \mathrm{Fe}_{2} \mathrm{O}_{3}$ ratio in spinel (Sp)-magnetite (Mt) inclusions vs. (a) the $\mathrm{Mg} \#$ of their olivine host; and (b) the anorthite content (An \%) of their plagioclase host. 
Table 5

Representative analyses of $\mathrm{Cr}$-spinel (1-3) and magnetite $(4,5)$ crystals included in olivine host from the Zavaritsky Vent (mass\%)

\begin{tabular}{lrrrrr}
\hline & \multicolumn{1}{c}{1} & \multicolumn{1}{l}{3} & \multicolumn{1}{l}{4} & \multicolumn{1}{l}{5} \\
\hline $\mathrm{TiO}_{2}$ & 0.52 & 0.71 & 0.94 & 9.51 & 9.48 \\
$\mathrm{Al}_{2} \mathrm{O}_{3}$ & 13.17 & 12.01 & 11.12 & 4.75 & 3.89 \\
$\mathrm{Cr}_{2} \mathrm{O}_{3}$ & 45.42 & 39.70 & 32.40 & 2.99 & 0.34 \\
$\mathrm{Fe}_{2} \mathrm{O}_{3}$ & 11.65 & 16.24 & 24.33 & 45.38 & 46.62 \\
$\mathrm{FeO}$ & 17.80 & 22.35 & 24.00 & 33.28 & 35.18 \\
$\mathrm{MnO}$ & 0.31 & 0.39 & 0.42 & 0.39 & 0.38 \\
$\mathrm{MgO}$ & 10.54 & 7.29 & 6.35 & 4.82 & 3.62 \\
Total & 99.44 & 98.77 & 99.61 & 101.12 & 99.51 \\
\hline
\end{tabular}

tent. Clinopyroxene (Fig. 8c) and orthopyroxene (Fig. 8d, Table 4) included in Mg-rich olivine are also Mg-rich and show positive correlations with the $\mathrm{Mg} \#$ of the olivine host. The occurrence of clinopyroxene and orthopyroxene inclusions with $\mathrm{Mg} \# \geq 90$ suggest that pyroxene began crystallizing almost simultaneously with olivine.

Olivine (Fig. 8e) and clinopyroxene (Fig. 8f) included in plagioclase have low Mg\#'s suggesting that plagioclase began to form late in the crystallization sequence. This is also shown by opaque oxide inclusions. The compositions of spinel/magnetite included within olivine and plagioclase crystals are shown on Fig. 9. In opaque oxides included in olivine, the $\mathrm{Cr}_{2} \mathrm{O}_{3}, \mathrm{MgO}$ concentrations, and $\mathrm{FeO} /$ $\mathrm{Fe}_{2} \mathrm{O}_{3}$ ratio decreases systematically as the $\mathrm{Mg \#}$ decreases (Fig. 9a, Table 5). The $\mathrm{FeO} / \mathrm{Fe}_{2} \mathrm{O}_{3}$ ratio and $\mathrm{Cr}_{2} \mathrm{O}_{3}$ content decline sharply in the opaque oxides when the $\mathrm{Mg \#}$ of the olivine host decreases from 76 to 73 . Only magnetite is crystallized in association with low $\mathrm{Mg \#}$ olivines. All opaque oxide inclusions in plagioclase (Fig. 9b) are Cr-poor, similar to those found in olivine hosts with $\mathrm{Mg \#}<$ 73. Plagioclase is clearly a late crystallizing phase. This is further supported by the observation that plagioclase inclusions do not occur in olivine and clinopyroxene with $\mathrm{Mg \#}>78$ and 76 , respectively.

\section{Discussion}

The HMB's and HAB's display a higher degree of correlated chemical variability and together, the two groups form a clearly defined continuous field of chemical variation (Fig. 3). The chemical trends define changes in the melt compositions of the Klyuchevskoy volcano and show that the chemical evolution has been very coherent. These data suggest that the HAB and HMB of the Klyuchevskoy volcano are genetically related and define a single evolutionary sequence.

The systematic decreases of $\mathrm{MgO}$ and $\mathrm{CaO}$ and increase of $\mathrm{TiO}_{2}, \mathrm{~K}_{2} \mathrm{O}$ and $\mathrm{Na}_{2} \mathrm{O}$ are consistent with evolution of the magmas by fractional crystallization of olivine and pyroxene. The increases of $\mathrm{Al}_{2} \mathrm{O}_{3}$, $\mathrm{Na}_{2} \mathrm{O}$ and $\mathrm{K}_{2} \mathrm{O}$ show that plagioclase fractionation was probably minimal, also the increasing $\mathrm{TiO}_{2}$ shows that magnetite was not on the liquidus and was not fractionated. As chrome-spinel is common as inclusions in olivine and clinopyroxene, it must have been a liquidus phase and also have fractionated during the evolution of HMB to HAB.

The composition and occurrence of mineral inclusions show a crystallization sequence beginning with high-magnesium olivine ( $\mathrm{Mg} \#$ 90-89) and $\mathrm{Cr}$-rich spinels, followed almost simultaneously by olivine (Mg\# 89-88), and clino- and orthopyroxene ( $\mathrm{Mg \#}$ 89-88). Eutectic crystallization of olivine, spinel, and the two pyroxenes continued until the $\mathrm{Al}$ content in the evolving coexisting melt increased sufficiently to allow plagioclase crystallization. Plagioclase crystallization began when olivine and clinopyroxene reached $\mathrm{Mg \#}$ of 77 and 75, respectively. Plagioclase then crystallized over a wide range of compositions $\left(\mathrm{An}_{84-42}\right)$ concomitant with olivine and pyroxene with $\mathrm{Mg} \#<75$. With the crystallization of plagioclase, the $\mathrm{Cr}$-spinels were replaced by magnetite. The last phases to crystallize were microlites of olivine and pyroxene with Mg\#'s of 65 and plagioclase of $\mathrm{An}_{42}$.

The geochemical and mineralogical data suggest the HMB to HAB series of the Klyuchevskoy volcano, formed as a result of fractionation of a primitive HMB. The parental magma was in equilibrium with high-magnesia olivine and clinopyroxene $(\mathrm{Mg \#}$ 91) and chrome-spinel, which represent the earliest paragenesis of crystallizing minerals. The fractionation of their phases resulted in a decrease of $\mathrm{MgO}$ and $\mathrm{CaO}$ in the melt and complementary enrichment of $\mathrm{Al}_{2} \mathrm{O}_{3}, \mathrm{CaO}$ and $\mathrm{K}_{2} \mathrm{O}$.

The fractionation model has been tested using COMAGMAT software of polybaric fractionation of high-magnesia magma of the Klyuchevskoy volcano 


\begin{tabular}{|c|c|c|c|c|c|c|c|c|c|c|c|c|c|c|c|}
\hline \multicolumn{4}{|c|}{$\begin{array}{l}\text { Composition } \\
\text { of minerals }\end{array}$} & \multirow{2}{*}{$\mathrm{F}$} & \multirow[t]{2}{*}{ Fractionation of minerals, wt \% } & \multirow{2}{*}{ P, kbar } & \multirow{2}{*}{$\mathrm{T},{ }^{0} \mathrm{C}$} & \multicolumn{8}{|c|}{ Natural and model melt compositions } \\
\hline $\mathrm{OL}$ & $\mathrm{CPX}$ & OPX & $\mathrm{Pl}$ & & & & & $\mathrm{SiO}_{2}$ & $\mathrm{TiO}_{2}$ & $\mathrm{Al}_{2} \mathrm{O}_{3}$ & $\mathrm{FeO}$ & $\mathrm{MgO}$ & $\mathrm{CaO}$ & $\mathrm{Na}_{2} \mathrm{O}$ & $\mathrm{K}_{2} \mathrm{O}$ \\
\hline 79 & 77 & 82 & \multirow{9}{*}{7} & $\mid 37$ & & 7.0 & 1104 & 53.5 & 1.1 & 18.3 & 8.7 & 5.2 & 82 & 35 & 12 \\
\hline 80 & 78 & 83 & & 35 & & 7.8 & 1118 & 53.1 & 1.1 & 18.0 & 9.1 & 5.5 & 8.3 & 3.6 & 0.9 \\
\hline 82 & 81 & 84 & & 30 & & 9.4 & 1154 & 52.8 & 1.1 & 17.3 & 9.2 & 6.3 & 8.8 & 3.4 & 0.9 \\
\hline 84 & 83 & 86 & & 25 & & 11.1 & 1189 & 52.5 & 1.0 & 16.6 & 9.2 & 7.1 & 9.3 & 3.2 & 0.8 \\
\hline 86 & 85 & 87 & & 20 & & 12.7 & 1225 & 52.1 & 1.0 & 15.9 & 9.2 & 8.1 & 9.6 & 3.0 & 0.8 \\
\hline 87 & 87 & 88 & & 15 & & 14.4 & 1254 & 52.6 & 1.0 & 15.4 & 9.0 & 8.7 & 9.5 & 2.8 & 0.7 \\
\hline 88 & 88 & & & 10 & & 16.0 & 1285 & 52.4 & 0.9 & 14.4 & 8.9 & 9.5 & 9.7 & 2.7 & 0.7 \\
\hline 89 & 89 & & & 5 & & 17.7 & 1315 & 52.1 & 0.9 & 14.4 & 8.9 & 10.4 & 9.8 & 2.6 & 0.7 \\
\hline \multirow[t]{2}{*}{90} & \multirow[t]{2}{*}{90} & & & 0 & & 19.3 & 1351 & 51.8 & 0.9 & 13.9 & 8.8 & 11.6 & 9.7 & 2.5 & 0.6 \\
\hline & & & & & & & & & & & & & & & \\
\hline
\end{tabular}

Fig. 10. Results of computer modeling of the formation of high-alumina basalts of the Klyuchevskoy volcano by the decompression fractionation mechanism. Computation was performed using COMAGMAT-3.0 software (Ariskin et al., 1993). The composition of the average high-magnesia basalt of the Klyuchevskoy volcano taken as the primary magma composition is given within the lower frame; the composition of the average high-alumina basalt of Klyuchevskoy volcano is given within the upper frame (Ariskin et al., 1995); $F$ is the degree of melt crystallization (wt.\%). Olivine, clino-, and orthopyroxene compositions are given in terms of magnesium number (Mg\#); plagioclase is characterized by anorthite content, mol\%. The modeled melt compositions are reduced to those in water-free system and adjusted to $100 \mathrm{wt} \%$.

(Ariskin et al., 1993). Calculation of more than 600 fractional crystallization models, assuming a parental high-magnesian basalt under polybaric (0-20 kbars) conditions, were performed for water-free and water-containing systems (Ariskin et al., 1995). Oxygen fugacity was assumed to be controlled by the quartz-fayalite-magnetite (QFM) buffer.

Model results are given in Fig. 10. The models show that HAB melts can be formed from HMB melts in a water-bearing system when crystallization and fractionation occurred as pressure decreased from 19 to $7 \mathrm{kbar}$. The calculated temperatures were from $1350^{\circ} \mathrm{C}$ to $1100^{\circ} \mathrm{C}$. About $2 \% \mathrm{H}_{2} \mathrm{O}$ is necessary in the parental melt to account for the formation of the entire composition range of basalts at Klyuchevskoy volcano. The models give the proportions of the fractionating minerals, which are consistent with the observed chemical trends. The mineral compositions (Fig. 10) in the model are also in agreement with the observed microprobe data.

Therefore, fractional crystallization within the vertical feeding system of the volcano is the most likely mechanism, providing the observed diversity of the Klyuchevskoy volcano basalts. Geophysical data suggest the magma erupted at the volcano is fed directly from the mantle and is not stored in crustal magma chambers (Fedotov et al., 1988; Ozerov et al., 1997a). Hence, the magmatic system is assumed to be a permanently active column, within which fractionation occurs as the crystallizing magma decompresses. HMB's with the most magnesium-rich mineral compositions occur at the greatest depths and gradually grade up to the most fractionated HAB. Fractionation is also likely to continue at shallow depths along the whole magmatic column. Crystallization of the mafic minerals, which originated at greater depths, and plagioclase continue as the magma rises. This results in the formation of more and more aluminous magmas of lower density. This concept is in good agreement with the data on density characteristics of magmatic material in the feeding system of the Klyuchevskoy volcano (Fedotov, 1993).

\section{Conclusions}

Detailed electron microprobe analyses of the main mineral phases and associated mineral inclusions 
have allowed the reconstruction of crystallization trends in calc-alkaline HAB from the Klyuchevskoy volcano, Kamchatka. The earliest phases to crystallize were olivine $\left(\mathrm{Mg} \#\right.$ 91), chrome-spinel $\left(\mathrm{Cr}_{2} \mathrm{O}_{3}\right.$ 46 wt. $\%, \mathrm{MgO} 11$ wt. $\%, \mathrm{TiO}_{2} 0.5$ wt. $\%$ ), clinopyroxene $\left(\mathrm{Mg} \#\right.$ 91, $\left.\mathrm{En}_{49} \mathrm{Wo}_{43} \mathrm{Fs}_{6}\right)$, and orthopyroxene ( $\mathrm{Mg} \#$ 89, $\left.\mathrm{En}_{86} \mathrm{Wo}_{3} \mathrm{Fs}_{11}\right)$. Plagioclase did not crystallize until the mafic phases reached $\mathrm{Mg \#} \sim 75$, at which time the chrome-spinel was replaced by magnetite crystallization. From the mineral paragenesis, it is apparent that the HAB and HMB are genetically related and form a part of a continuous differentiation sequence which evolved from a single highmagnesium parental melt. Fractionational crystallization of olivine and clinopyroxene with minor $\mathrm{Cr}-$ spinel can best explain the evolution of the magmas.

The results of fractionation models obtained using COMAGMAT-3.0 indicate that the fractionational crystallization of the primary HMB magma occurred as pressure decreased from 19 to $7 \mathrm{kbar}$, at temperatures of $1350^{\circ} \mathrm{C}$ to $1110^{\circ} \mathrm{C}$, and approximately $2 \%$ $\mathrm{H}_{2} \mathrm{O}$ in the primary melt. Such a fractionation regime provides for the formation of HAB identical to those at Klyuchevskoy volcano by fractionation of $36 \%$ mafic phases.

\section{Acknowledgements}

This article is dedicated to the memory of Igor A. Menyaylov, Institute of Volcanology, who was killed on the 14th of January 1993 during an eruption of Galeras Volcano, Columbia. Igor was a good friend, mentor, and assisted the author's study of Klyuchevskoy greatly. Thanks to Dr. S.A. Khubunaya for providing the HMB samples. Microprobe analyses were made with the assistance of Valerie Ananev and Vladimir Chubarov at the Institute of Volcanology (Russian Academy of Sciences), PetropavlovskKamchatsky. Preparation of this manuscript started while the author was visiting New Mexico Institute of Mining and Technology, Socorro, under the support of NSF grant EAR-9117815 to Dr. Philip Kyle. The author would like to thank Dr. Philip Kyle for his great assistance in editing and preparing the manuscript for publication and Dr. Nelia Dunbar and Richard Esser for early comments on the manuscript. Support was also provided through grants (97-05-
64541 and 98-05-64677) from the Russian Foundation of Fundamental Research.

\section{References}

Ariskin, A.A., Frenkel, M.Ya., Barmina, G.S., Nielsen, R.L., 1993. COMAGMAT: a Fortran program to model magma differentiation processes. Comput. Geosci. 19, 1155-1170.

Ariskin, A.A., Barmina, G.S., Ozerov, A.Yu., Nielsen, R.L., 1995. Genesis of high-alumina basalts from Klyuchevskoy volcano. Petrology 3 (5), 449-472, Translated from Petrologiya, Vol. 3, No. 5, 1995, 496-521.

Baker, D.R., Eggler, D.H., 1983. Fractionation paths of Atka (Aleutians) high-alumina basalts; constraints from phase relations. J. Volcanol. Geotherm. Res. 18, 387-404.

Brophy, J.G., 1989. Can high-alumina arc basalt be derived from low-alumina arc basalt?; evidence from Kanaga Island, Aleutian Arc, Alaska. Geology 17, 333-336.

Brophy, J.G., Marsh, B.D., 1986. On the origin of high alumina arc basalt and the mechanics of melt extraction. J. Petrol. 27, 763-789.

Draper, D.S., Johnston, A.D., 1992. Anhydrous PT phase relations of an Aleutian high-MgO basalt; an investigation of the role of olivine-liquid reaction in the generation of arc high-alumina basalts. Contrib. Mineral. Petrol. 112, 501-519.

Fedotov, S.A., 1993. Magmatic feeding system and activity mechanism of Klyuchevskoy volcano. Vulkanol. Seismol. 3, 23-45, in Russian.

Fedotov, S.A., Zharinov, N.A., Gorel'chik, V.I., 1988. Deformation and earthquakes at Klyuchevskoy volcano: a model for its eruptive activity. Vulkanol. Seismol. 2, 3-42, in Russian.

Fournelle, J., Marsh, B.D., 1991. Shishaldin Volcano; Aleutian high-alumina basalts and the question of plagioclase accumulation. Geology 19, 234-237.

Johnston, A.D., 1986. Anhydrous P-T phase relations of nearprimary high-alumina basalt from the South Sandwich Island: implications for the origin of island arcs and tonalitetrondhjemite. Contrib. Mineral. Petrol. 92, 24-38.

Kadik, A.A., Rozenhauer, M., Lukanin, O.A., 1989. Experimental study of pressure influence on the crystallization of Kamchatka magnesian and aluminous basalts. Geochemistry 12, $1748-1762$, in Russian.

Kay, S.M., Kay, R.W., 1985. Aleutian tholeiitic and calc-alkaline magma series: 1 . The mafic phenocrysts. Contrib. Mineral. Petrol. 90, 276-290.

Kelemen, P.B., 1990. Reaction between ultramafic rock and fractionating basaltic magma: I. Phase relations, the origin of calc-alkaline magma series, and the formation of discordant dunite. J. Petrol. 31, 51-98.

Kersting, A.B., Arculus, R.J., 1994. Klyuchevskoy Volcano, Kamchatka, Russia; the role of high-flux recharged, tapped, and fractionated magma chamber(s) in the genesis of high$\mathrm{Al}_{2} \mathrm{O}_{3}$ from high-MgO basalt. J. Petrol. 35, 1-41.

Kersting, A.B., Arculus, R.J., 1995. Pb isotope composition of Klyuchevskoy Volcano, Kamchatka and North Pacific sedi- 
ments; implications for magma genesis and crustal recycling in the Kamchatkan arc. Earth Planet. Sci. Lett. 136, 133-148.

Khrenov, A.P., Antipin, V.S., Chuvasheva, L.A., Smirnova, E.V., 1989. Petrochemical and geochemical properties of basalts from Klyuchevskoy volcano. Vulkanol. Seismol. 3, 3-15, in Russian.

Kuno, H., 1960. High-alumina basalt. J. Petrol. 1, 121-125.

Marsh, B.D., Carmichael, I.S.E., 1974. Benioff zone magmatism. J. Geophys. Res. 79, 1196-1206.

Ozerov, A.Yu., Khubunaya, S.A., 1992. Chemistry of olivines and pyroxenes as an indicator of the genetic relationship between high-alumina and magnesium basalts of Klyuchevskoy volcano. In: Post-eruptive Mineral Formation on Active Volcanoes of Kamchatka. Vladivostok, Part II, 37-61 (in Russian).

Ozerov, A.Yu., Ariskin, A.A., Barmina, G.S., 1996. The problem of genetic relations between high-alumina and high-magnesian basalts of the Klyuchevskoy volcano, Kamchatka. Transactions (Doklady) of the Russian Academy of Sciences/Earth Science Sections, Vol. 350, No. 7, 1127-1130. Translated from Doklady Akademii Nauk, Vol. 350, No. 1, 1996, 104107.

Ozerov, A.Yu., Ariskin, A.A., Kyle, P.R., Bogoyavlenskaya, G.E., Karpenko, S.F., 1997a. Petrological-geochemical model for genetic relationships between basaltic and andesitic magmatism of Klyuchevskoy and Bezymyannyi volcanoes, Kamchatka. Petrology 5 (6), 550-569, Translated from Petrologiya, Vol. 5, No. 6, 1997, 614-635.

Ozerov, A.Yu., Karpov, G.A., Droznin, V.A., Dvigalo, V.N., Demyanchuk, Yu.V., Ivanov, V.V., Belousov, A.B., Firstov, P.P., Gavrilov, V.A., Yaschuk, V.V., Okrugina, A.I., 1997b. The September 7-October 2, 1994 eruption of Klyuchevskoi Volcano, Kamchatka. Volcanol. Seismol. 18 (5), 501-516.

Perfit, M.R., Gust, D.A., Bence, A.E., Arculus, R.J., Taylor, S.R., 1980. Chemical characteristics of island-arc basalts; implications for mantle sources. Chem. Geol. 30, 227-256.

Volynets, O.N., Ermakov, V.A., Kirsanov, I.T., Doubik, Yu.M., 1976. Petrochemical types of the Quaternary Kamchatka volcanoes. Bull. Vulkanol. Stations 52, 115-126, in Russian. 